\title{
Effective strategy for managing H7N9 virus infection
}

\author{
S. Wiwanitkit $\cdot$ V. Wiwanitkit
}

Received: 17 October 2013/ Accepted: 31 October 2013/Published online: 14 November 2013

(C) Springer-Verlag Berlin Heidelberg 2013

\section{Sir,}

We read with great interest the article by Song et al. entitled "Surveillance of the first case of human avian influenza A (H7N9) virus in Beijing" that recently appeared in Infection [1]. These authors reported that "Early diagnosis and early initiation of the treatment of confirmed infections is the most effective strategy" for managing H7N9 virus infection. However, how to effectively manage the problem of H7N9 virus infection itself is a topic for further discussion. As Song et al. also mention, some cases can be asymptomatic [2], and the correct diagnosis might not be easy in such cases, and sometimes even impossible. In the absence of symptoms, the physician may be less concerned about possible infectivity and fail to make a diagnosis. It is therefore important that there be a guideline for the decision-making process to perform-or not-a diagnostic test. A key question is just how extensive should the screening test be to serve the aim of achieving an early diagnosis. Whether routine surveillance is cost effective or not requires further study. A focus on the early initiation of treatment does not necessarily mean that case management will be successful. The problem of antiviral drug resistance should be kept in mind [3]. The most effective approach to managing the problem of H7N9 virus infection is to educate the general public on those aspects of healthcare, such as self-prevention and promotion of basic sanitation, which relate to the transmission of respiratory infections. The development of a specific vaccine is also to be hoped for.

Conflict of interest None.

\section{References}

1. Song R, Pang X, Yang P, Shu Y, Zhang Y, Wang Q, Chen Z, Liu J, Cheng J, Jiao Y, Jiang R, Lu L, Chen L, Ma J, Li C, Zeng H, Peng X, Huang L, Zheng Y, Deng Y, Li X. Surveillance of the first case of human avian influenza A (H7N9) virus in Beijing, China. Infection. 2013. doi:10.1007/s15010-013-0533-9

2. Editorial Team. Guideline on prevention and control of H7N9 avian influenza human infection. J Thorac Dis. 2013;5[Suppl 2]:S168-72.

3. Hay AJ, Hayden FG. Oseltamivir resistance during treatment of H7N9 infection. Lancet. 2013;381(9885):2230-2.

S. Wiwanitkit $(\square)$

Wiwanitkit House, Bangkhae, Bangkok, Thailand

e-mail: somsriwiwan@hotmail.com

V. Wiwanitkit

Hainan Medical University, Hainan, China

V. Wiwanitkit

Joseph Ayobabalola University, Ikeji-Arakeji, Nigeria

V. Wiwanitkit

Faculty of Medicine, University of Nis, Nis, Serbia 